\title{
Anti-hypertensive medicines prescribing for medical outpatients in a premier teaching hospital in Nigeria: a probable shift of paradigm
}

\author{
Unyime I. ESHIET, Kazeem B. YUSUFF.
}

\author{
Received (first version): 14-Feb-2014 Accepted: 11-May-2014
}

\begin{abstract}
${ }^{*}$
Background: Previous studies of anti-hypertensive medicines utilization pattern in Nigeria showed that Angiotensin converting enzyme inhibitors (ACEls) were often the least prescribed. However, the appropriate use of ACEls in the black population achieves good blood pressure control and provides additional long term cardioand renovascular protection benefits.

Objective: To assess the current utilization pattern of antihypertensive medicines with specific emphasis on identifying possible shift in the frequency of use of ACEls. Methods: A prospective cross-sectional assessment of the current utilization pattern of anti-hypertensive medicines was conducted among 300 randomly selected cohort at a 900-bed premier Teaching Hospital located in Ibadan, Southwestern Nigeria. The current utilization pattern was compared with the results of a study conducted at the same site and published 10 years ago. Results: Of the 300 random cohorts, a majority $(79 \%)$ were females (237) with mean age 58.7 years $(S D=2.81$ years. Stage 2 hypertension was the most frequent diagnosis (54.3\%). The utilization of ACEls and long acting CCB (amlodipine) significantly increased from $8.6 \%$ and $21 \%$ (Ten years ago) to $29.93 \%$ and $36.68 \%$ respectively $(p<0.0001)$. The use of thiazide diuretic and methyldopa declined significantly from $39.4 \%$ and $23.3 \%$ (Ten years ago) to $16.12 \%$ and $9.7 \%$ respectively $(p<0.0001)$. Adverse drug reactions due to ACEls were documented in $1.5 \%$ (3), while laboratory monitoring of serum potassium, urea and creatinine was conducted in only $37 \%$ (111) of cohort. Potentially harmful drug-drug interactions were identified in $25 \%$ (75) of cohorts, and the most frequent were ACEls + NSAIDs (53.3\%), ACEls + amiloride / hydrochlorothiazide $(22.6 \%)$.

Conclusions: Anti-hypertensive medicines utilization has significantly shifted towards the increased use of ACEls and long acting dihydropyridine CCBs. The use of thiazides and methyldopa has declined significantly. Physicians appeared more cognizant of the long term cardio- and renovascular benefits inherent in using ACEls in a high cardiovascular risk group such as black hypertensive.
\end{abstract}

Keywords: Antihypertensive Agents; AngiotensinConverting Enzyme Inhibitors; Calcium Channel Blockers; Drug Utilization; Nigeria

\section{INTRODUCTION}

Untreated or poorly treated hypertension is a known predictor of negative coronary artery and cerebrovascular events, and increased morbidity and mortality associated with cardiovascular diseases. $^{1-3}$ Hence, adequate control of blood pressure levels to a defined target with appropriate, effective, safe and convenient anti-hypertensive medicines is an important determinant of cardiovascular risk reduction among hypertensive patients. $^{4-6}$ Hypertension is an underdiagnosed chronic disease that remains a daunting public health challenge in Nigeria. Notwithstanding a reported prevalence $10 \%$ in both urban and rural settings, awareness of blood pressure status remain low, and patients who are lucky to be diagnosed in a formal health care setting often present late and with chronic complications associated with endorgan damage due to malignant hypertension. ${ }^{7,8}$

Several studies including one that we conducted and published about ten years ago (June-August 2002) have documented a consistent trend in the prescribing pattern of anti-hypertensive medicines in Nigeria. ${ }^{9}$ The results often shows thiazide diuretics as the most prescribed anti-hypertensive medicines, followed by short-acting dihydropyridine calcium channel blockers and centrally-acting agent such as methyldopa. Angiotensin converting enzyme inhibitors were often one of the least prescribed anti-hypertensive medicine classes ${ }^{10-14}$, while angiotensin receptor blockers were rarely prescribed and used for the management of hypertension in Nigeria at that period. Our previous study of anti-hypertensive medicines utilization pattern about 10 years ago showed that ACEls and beta blockers were the least frequently prescribed. $^{9}$ The sparse prescribing of ACEls was associated with the reported relatively lower reduction of blood pressure by ACEls in the black population especially as monotherapy. ${ }^{15,16}$ However, this view was challenged by a number of studies which showed that blood pressure response to ACEls is probably blind to race but sensitive to patients' factors such as age, body mass index, high entry/baseline blood pressure levels and severe hypertension due to delay in seeking treatment, presence of co-morbidity such as diabetes mellitus and inequity in the access to functional health care. ${ }^{17,18}$ Furthermore, the appropriate use of the combination of ACEls with thiazide diuretics in black hypertensive population have been shown to achieve good blood pressure control and improved cardio- and renovascular protection. ${ }^{19,20}$ Hence, ACEls appear to provide additional long term

\footnotetext{
*Unyime I. ESHIET. MPharm. Department of Clinical Pharmacy \& Pharmacy Administration, Faculty of Pharmacy, University of Ibadan. Ibadan (Nigeria). Kazeem B. YUSUFF. PhD. Department of Clinical Pharmacy, University of Ibadan \& Assistant Professor Department of Pharmacy Practice, College of Clinical Pharmacy, King Faisal University, Hofuf Al-Ahsa, (Saudi Arabia).yusuffkby@yahoo.co.uk
} 
benefits beyond adequate control of blood pressures to a defined target. This is important for the black hypertensive patients that are usually at the highest risk of poor prognosis associated with adverse cardiovascular and cerebrovascular events, and higher prevalence of malignant hypertension, chronic kidney disease, left ventricular hypertrophy, congestive heart failure, ischeamic heart disease and myocardial infarction. ${ }^{21,22}$ Despite the documented evidence of therapeutic benefits associated with the use of ACEls in black hypertensive patients, studies continue to show that they are one of the least frequently prescribed in Nigeria. The objective of the study was to assess the current utilization of anti-hypertensive medicines with a specific emphasis on identifying possible shift in the frequency of use of ACEls

\section{METHODS}

A cross-sectional assessment of the antihypertensive medicines utilization was conducted between $1^{\text {st }}$ June and $31^{\text {st }}$ June 2012 among 300 randomly selected hypertensive patients diagnosed and managed at the Medical Outpatient Clinic of the University College Hospital (UCH), Ibadan. This is a 900-bed premier Teaching Hospital with medical residents located in Ibadan, Southwestern Nigeria. It is affiliated with the University of Ibadan and serves as a major tertiary referral center in Nigeria. UCH has fifty-two service and clinical departments and runs seventy-five consultative outpatient clinics per week in forty-five specialties and sub-specialties. Ibadan, where the study site is located, is one of the largest cities in sub-Saharan Africa and consisted of 11 local government areas. It has an estimated population of 2.5 million consisting of varied backgrounds and ethnicities. Ethical clearance and approval of the study protocols was granted by the Joint University of Ibadan/University College Hospital Research and Ethics Committee. All the patients who presented at the Hypertension unit of the Medical Outpatient Clinics at the study site within the study period were included and constituted the sample frame. The average number of patients seen at the weekly Hypertension clinic was 90. Patient selection was done after clinic appointment cards had been collected and patients were seated in the waiting area. Seventy-five clinic appointment cards were randomly drawn weekly from the collected pool. The case notes of the selected seventy five patients were retrieved for data extraction after physicians' consultation.

Data were extracted from the case notes of the randomly selected 300 patients using pre-tested data collection instruments. The first draft of the instrument was pre-tested with the case notes of ten patients at the study site to assess completeness and relevance of data capture. The final draft of the instrument was modified based on the results of pre-testing, but the data collected during pre-testing was not included in the final result. The data collected from patients' case notes were:

i) Patients' hospital number, Age and Gender ii) Systolic and diastolic blood pressure readings at first clinic attendance.

iii) Systolic and diastolic blood pressure readings at last clinic attendance

iv) Hypertension diagnosis and co-existing diseases.

v) Antihypertensive drugs prescribed with specific focus on ACEls and ARBs.

vi) Documentation of adverse drug reactions associated with ACEls /ARBs

vii) .Baseline and follow-up laboratory monitoring for serum potassium, urea and creatinine

viii)Monthly cost of antihypertensive drugs and Monthly cost of ACE inhibitors and ARBs.

ix) Potential Drug-drug interactions and contraindications

The classification of hypertension diagnosis was based on the Seventh report of the Joint National Committee for the prevention, detection, evaluation and treatment of hypertension, and the average systolic / diastolic blood pressure reading recorded at the first clinic attendance were used for the hypertension diagnosis. The documented systolic and diastolic blood pressure levels at the last clinic attendance was adjudge as adequately controlled if they are less than $140 / 90 \mathrm{mmHg}^{23}$ The appropriateness of the antihypertensive drug doses, dosing interval and potentially harmful drug interactions were assessed using the British National Formulary (March, 2010). ${ }^{24}$ Data analysis was carried out with descriptive and chi-square statistics using Statistical Program for the Social Sciences (SPSS) version 15.0 with $p<0.05$ considered significant.

\section{RESULTS}

The clinico-demographic profile of the random 300 cohort studied is as shown in Table 1. The majority $(79 \%)$ of the cohort were females (237) with mean age of $58.66(\mathrm{SD}=2.81$ ) years (minimum-maximum, 33-97 years). Stage 2 hypertension was the most frequent diagnosis $(54.3 \%)$ followed by stage 1 hypertension $(27.7 \%)$ and isolated systolic hypertension (18\%). The most frequently diagnosed co-existing diseases were osteoarthritis (38.2\%), malaria $(22.92 \%)$ and diabetes mellitus $(20.14 \%)$. Overall, blood pressure control was documented as adequate in $33 \%$ (96) of cohort.

Calcium channel blockers (36.68\%) and Angiotensin converting enzyme inhibitors (ACEIs) $(29.93 \%)$ were the most frequently prescribed antihypertensive medicine classes. Diuretics, centrally acting agents, and angiotensin II receptor blockers (ARBs) were prescribed in $16.12 \%, 9.7 \%$ and $3.13 \%$ of cohort respectively (Table 2 ).

Amlodipine (78.5\%) and ramipril (55.5\%) were the most frequently prescribed calcium channel blocker and ACEls respectively. Amiloride/hydrochlorothiazide combination accounted for $86.73 \%$ of prescribed thiazide diuretics, while losartan accounted for $94.74 \%$ of the ARBs prescribed. Methyldopa, atenolol and spironolactone were the only centrally acting agent, beta blocker and aldosterone antagonist prescribed 


\begin{tabular}{|c|c|c|}
\hline $\begin{aligned} & \text { Age }(\text { years })(n=300) \text { Mean age male } \\
& \text { Mean age female }\end{aligned}$ & & $\begin{array}{l}66.06(\mathrm{SD}=3.11) \\
58.66(\mathrm{SD}=2.81)\end{array}$ \\
\hline & $\mathrm{n}$ & $\%$ \\
\hline Gender $(n=300)$ & $\begin{array}{c}237 \\
63\end{array}$ & $\begin{array}{l}79 \\
21\end{array}$ \\
\hline $\begin{array}{r}\text { Stage } 2 \text { hypertension } \\
\text { Stage } 1 \text { hypertension } \\
\text { Isolated systolic hypertension } \\
\end{array}$ & $\begin{array}{l}163 \\
83 \\
54\end{array}$ & $\begin{array}{l}54.3 \\
27.7 \\
18.0\end{array}$ \\
\hline $\begin{array}{r}\text { Osteoarthritis } \\
\text { Malaria } \\
\text { Diabetes mellitus } \\
\text { Peptic ulcer disease } \\
\text { Congestive heart failure } \\
\text { Asthma } \\
\text { Psychosis } \\
\text { Impaired vision } \\
\text { Renal dysfunction } \\
\text { Stroke } \\
\text { Left ventricular hypertrophy } \\
\text { Benign prostatic hyperplasia }\end{array}$ & $\begin{array}{c}55 \\
33 \\
29 \\
9 \\
8 \\
2 \\
2 \\
2 \\
1 \\
1 \\
1 \\
1 \\
\end{array}$ & $\begin{array}{c}38.2 \\
22.92 \\
20.10 \\
6.25 \\
5.6 \\
1.39 \\
1.39 \\
1.39 \\
0.69 \\
0.69 \\
0.69 \\
0.69 \\
\end{array}$ \\
\hline $\begin{array}{l}\text { Laboratory Monitoring Tests }(n=300) \\
\text { (Electrolytes, urea and creatinine levels) }\end{array}$ & $\begin{array}{c}189 \\
104 \\
7\end{array}$ & $\begin{array}{c}63 \\
34.7 \\
2.3\end{array}$ \\
\hline $\begin{array}{r}\text { Cost of anti-hypertensive medicines } \\
\text { Mean monthly cost of anti-hypertensive medicines } \\
\text { Mean monthly cost of ACE inhibitors }\end{array}$ & & $\begin{array}{l}\text { N } 1,784.71 \\
\text { N } 1,114.53\end{array}$ \\
\hline
\end{tabular}

in their respective classes (Table 2). Aspirin $(25.2 \%)$, clopidogrel $(12.5 \%)$ and Non-steroidal Anti-inflammatory Drugs (NSAIDs) were the most frequently non-anti-hypertensive medicines (Table 2). All patients made out of pocket payments for their medicines. The mean monthly cost of antihypertensive medicines was NGN1,784.71 ((USD11.09), while the mean monthly cost of ACEls and ARBs were NGN1,114.5 (USD6.92) and NGN1,376.47 (USD8.55) respectively. The antihypertensive and non-antihypertensive medicines' doses and dosing interval, as documented, were adequate and no contraindication was identified among the cohort studied.

Adverse drug reactions (ADRs) due to ACE1s were documented in $1.5 \%$ (3) of cohort with dry cough being the only ADR documented. There was no documentation of ADR for ARBs. Overall, laboratory monitoring of serum potassium, urea and creatinine was conducted in $37 \%$ (111) of cohorts. Of these (111), $93.7 \%$ (104) had baseline testing of these parameters, while only $6.3 \%$ (7) had both baseline and one follow-up testing conducted. Potentially harmful drug-drug interactions were identified in $25 \%$ (75) of cohorts. The most frequent potentiallyharmful interactions were ACEls + NSAIDs (53.3\%), ACEls + amiloride / hydrochlorothiazide (22.6\%), ACEls + spironolactone $(9.3 \%)$, ARBs + amiloride/hydrochlorothiazide $(5.3 \%)$ and ARBs + spironolactone $(5.3 \%)$ (Table 2 ).

\section{DISCUSSION}

The findings of our present study suggest a significant shift in anti-hypertensive prescribing pattern with a considerable increase in the frequency of use of ACEls and long acting dihyropyridine CCBs. On the other hand we observed a significant downward spiral in the frequency of use of thiazide diuretics $(39.4 \%)^{9}$ (ten year ago) to $16.12 \%$. These findings stand in sharp contrast to the anti-hypertensive medicine utilization pattern that we reported from the same study site about 10 years ago. ${ }^{9}$ The ACEls were one of the least frequently prescribed accounting for only $8.6 \%$ of prescribed anti-hypertensive medicines 10 years ago ${ }^{9}$; while the present study showed that the frequency of use has significantly risen to $29.9 \%$ $(p<0.0001)$. This is an important prescribing shift that is likely to contribute to reducing the negative cardiovascular events associated with malignant hypertension, and long term survival among hypertensive patients in Nigeria. The paradigm shift towards increased prescribing of ACEls probably suggest that clinicians are more cognizant of the long term cardio- and renovascular benefits inherent in using ACEls especially in a high cardiovascular risk group such as black hypertensive. However, we believe this is not readily clear and will require further studies to identify the factors underlining the significant increase in the prescribing of ACEls. In addition, the use of thiazide diuretics as first line anti-hypertensive agents among Nigerians with documented high co-morbidities such as diabetes appeared inappropriate ab initio. This is because the landmark Anti-hypertensive and Lipid Lowering Treatment to prevent Heart Attack Trial (ALLHAT) upon which the recommendation to use to thiazides as first line agent is premised reported an increased incidence of hypokalemia, hyperglycemia and newonset diabetes mellitus with thiazides relative to other anti-hypertensive agents such as ACEls, 


\begin{tabular}{|c|c|c|}
\hline $\begin{array}{l}\text { Table 2. Pattern of use of antihy } \\
\text { antihypertensive drugs. }\end{array}$ & rtensive & d non \\
\hline Antihypertensive drugs $(n=608)$ & number & $\%$ \\
\hline Calcium channel blockers $(n=223)$ & & 36.68 \\
\hline Amlodipine & 175 & 78.5 \\
\hline Nifedipine & 48 & 21.5 \\
\hline ACE Inhibitors $(n=182)$ & & 29.93 \\
\hline Ramipril & 101 & 55.5 \\
\hline Lisinopril & 59 & 32.4 \\
\hline Enalapril & 22 & 12.1 \\
\hline Thiazide diuretics $(n=98)$ & & 16.12 \\
\hline Amiloride + hydrochlorothiazide & 85 & 86.7 \\
\hline Hydrochlorothiazide & 13 & 13.3 \\
\hline Centrally acting agents $(n=59)$ & & 9.7 \\
\hline Methyldopa & 59 & 100 \\
\hline ARB $(n=19)$ & & 3.13 \\
\hline Losartan & 18 & 94.7 \\
\hline Valsartan & 1 & 5.3 \\
\hline Beta blockers $(n=15)$ & & 2.47 \\
\hline Atenolol & 15 & 100 \\
\hline Aldosterone antagonist $(n=12)$ & & 1.97 \\
\hline Spirinolactone & 12 & 100 \\
\hline Non-antihypertensive medicines $(n=360)$ & & \\
\hline Aspirin & 95 & 26.39 \\
\hline Clopidogrel & 73 & 20.28 \\
\hline Diclofenac & 37 & 10.28 \\
\hline Artemeter + lumefantrine & 33 & 9.17 \\
\hline Metformin & 25 & 6.94 \\
\hline Glucosamine + chondroitin & 14 & 3.89 \\
\hline Glimepiride & 14 & 3.89 \\
\hline Anxiolytics & 11 & 3.06 \\
\hline Calcium lactate & 10 & 2.78 \\
\hline Neurobion & 10 & 2.78 \\
\hline Meloxicam & 8 & 2.21 \\
\hline Mist.Magnesium Trisilicate & 6 & 1.67 \\
\hline Glibenclamide & 5 & 1.39 \\
\hline Orphenadrine & 5 & 1.39 \\
\hline Pioglitazone & 4 & 1.11 \\
\hline Antipsychotics & 4 & 1.11 \\
\hline Omeprazole & 3 & 0.83 \\
\hline Digoxin & 3 & 0.83 \\
\hline
\end{tabular}

ARBs and CCBs. ${ }^{25}$ Furthermore, other studies have also reported that the incidence of new-onset diabetes mellitus is highest with thiazides and lowest with ACEls, ARBs. ${ }^{26-29}$ Besides, the increased incidence of thiazide-associated hypokalemia is a known contributor to insulin resistance and poor glucose utilization by target tissues. $^{30,31}$ The long term macro- and microvascular complications associated with this biochemical derangement though well documented are open to confounding by the duration of follow-up and thus may not be readily apparent. Therefore, the shift in anti-hypertensive medicine prescribing pattern is a significant break from the past and it appeared to be based on evidence of obtainable short and long term therapeutic benefits.

The significant prescribing shift from the short acting dihydropyridine CCBs [Nifedipine: $88.2 \%$ (past) versus $21.5 \%$ (current)] reported 10 years ago to a long acting CCBs [amlodipine: $11.8 \%$ (past) versus $78.5 \% \%$ (current)] $(p<0.0001)$ also suggest physicians' greater awareness of the importance of using medications with less frequent dosing regimen to improve medication adherence, smoother and better blood pressure control. This is more likely to contribute to the achievement of optimal therapeutic outcomes among patients with hypertension. $^{32}$
The decline in the frequency of use of methyldopa between 10 years ago $(23.3 \%)^{9}$ and now $(9.7 \%)$ is also significant $(p<0.0001)$. Indeed, the current low frequency of methyldopa's use is consistent with its widely reported low or non-usage due to poor safety profile in other countries. ${ }^{23}$ The widespread availability and cheap acquisition cost of methyldopa, and probably prescribing dogma passed from generations of prescribers upon which the past considerable use of methyldopa was premised appeared to have waned ten years down the line. In addition, the increasing widespread availability of affordable generic version of antihypertensive medicine options with relatively better safety profiles appeared to contribute to the considerable decline in the use of methyldopa. Furthermore, the consideration of the negative impact of low patient adherence associated with medicines with poor ADRs profile such as methyldopa on cardiovascular outcomes in a high risk group such as Nigerian hypertensives may also be contributory.

The lack of an effective ADR monitoring, prevention, detection and documentation system which we reported ten years ago continue to be a sad phenomenon of health care delivery in Nigeria. It is thus unsurprising that ADRs associated with ACEIs and ARBs were documented in only $1.5 \%$ of cohorts. This observation is not indicative of low frequency of ADRs but suggest lack of a functional ADRs detection and documentation system. Our position is further supported by the results of the baseline and follow-up laboratory monitoring which showed that majority of patients prescribed ACEIs and ARBs were not adequately monitored with relevant laboratory parameters such serum potassium, urea and creatinine. Yet potentially harmful drug-drug interactions the impact of which could have been easily tracked with relevant laboratory parameters were identified in a majority $(75 \%)$ of patients. The co-prescribing of NSAIDs and ACEls in about half of the cohorts without close monitoring required to exclude any potential harms to patients appeared inappropriate and is potentially life-threatening. ${ }^{33,34}$ The reduced anti-hypertensive efficacy of medicine classes such as ACEls and thiazide diuretics when co-prescribed on a chronic basis with NSAIDs is well documented. ${ }^{35,36}$ However, the depth of the contribution of this drugdrug interactions to the observed low level of blood pressure control among the cohorts studied is not readily clear. In addition, the continuing high frequency of co-prescribing of ACEls and potassium-sparing diuretics such as amiloride + hydrochlorothiazide or aldosterone antagonist such as spironolactone may expose patients to negative cardiovascular events associated with hyperkalemia, especially with the observed poor baseline and follow-up monitoring of serum potassium and creatinine levels.

The result of this study is limited by the fact that patients were sampled at the major tertiary hospital (UCH) in Nigeria. However, the choice of $\mathrm{UCH}$ was because it is the premier teaching/tertiary hospital, and a major referral center for other health care centers in Nigeria. Furthermore, it is a major site for 
undergraduate and post-graduate residency training of physicians. Therefore, the tutelage and practices at $\mathrm{UCH}$ as a determinant of clinical practices and prescribing habits of physicians in other parts, or settings, in Nigeria was strongly considered. In addition, the lack of an integrated functional monitoring and documentation system to track patients' progress and long term outcomes of medication use in chronic medical conditions such as hypertension made such long term assessment almost impossible. Furthermore, patient selection appeared skewed towards the female gender. However, the mid-year random sampling strategy, a valid procedure commonly used in epidemiological study, may mitigate probable selection bias. In addition, the observed distribution pattern may also suggests that female hypertensive patients are probably more adherent with clinic attendance or perhaps seeking medical help for the management of hypertension at the study site in relatively greater proportion. This is a probable focus for future research.

\section{CONCLUSIONS}

Physicians' prescribing of anti-hypertensive medicines in Nigeria appeared to have significantly shift towards increased use of ACEls and long acting dihydropyridine CCBs, and decline in the use of thiazide diuretics and methyldopa. However, baseline and follow-up monitoring of relevant laboratory parameters to preclude potentiallyharmful adverse events and effective detection and documentation of ADRs remain inadequate.

\section{ACKNOWLEDGEMENT}

We acknowledge the guidance and support of Professor Fola Tayo (Retired Professor of Clinical Pharmacy), Health Systems Management Consultants Limited, No 1, Jubilee road, Magodo G.R.A. Phase II, Lagos, Nigeria

\section{CONFLICT OF INTEREST}

The authors declare no conflict of interest

Funding: None.

\section{PRESCRIPCION DE ANTIHIPERTENSIVOS PARA PACIENTES MÉDICOS AMBULATORIOS DE UN HOSPITAL UNIVERSITARIO EN NIGERIA: PROBABLE CAMBIO DE PARADIGMA}

\section{RESUMEN}

Antecedentes: anteriores estudios de patrones de utilización de antihipertensivos en Nigeria mostraron que los inhibidores de la enzima convertidora de angiotensina (IECA) eran a menudo los menos prescritos. Sin embargo, el uso apropiado de IECA en la población negra alcanza buen control de presión arterial y proporciona protección adicional cardio y renovascular a largo plazo.

Objetivo: Evaluar el patrón actual de utilización de antihipertensivos con especial énfasis en identificar potenciales cambios de frecuencia de uso de IECA. Métodos: Se realizó una evaluación transversal prospectiva de la actual utilización de antihipertensivos entre una cohorte de 300 individuos aleatoriamente seleccionados en un hospital universitario localizado en Ibadan, Sur-Oeste de Nigeria. Se comparó el patrón actual de utilización de resultados con un estudio realizado en la misma localización hace 10 años. Resultados: De los 300 individuos aleatorizados, la mayoría (79\%) eran mujeres (237) con una edad media de 58,7 años $(\mathrm{DE}=2,81)$. El diagnóstico más frecuente era la hipertensión en Estado 2 (54,3\%). La utilización de IECA y bloqueantes de canales de calcio (BCC) de larga acción (amlodipina) se aumentó significativamente de $8,6 \%$ y $21 \%$ (hace 10 años) a $29,93 \%$ y $36,68 \%$ respectivamente $(\mathrm{p}<0.0001)$. El uso de diuréticos tiazídicos y metildopa se redujo significativamente de $39,4 \%$ y $23,3 \%$ (hace 10 años) a $16,12 \%$ y $9,7 \%$ respectivamente $(\mathrm{p}<0.0001)$. Se documentaron reacciones adversas debidas a IECA en el 1,5\% (3) de los casos, mientras que se realizaron solo un $37 \%$ (111) de monitorizaciones laboratoriales de potasio sérico, urea y creatinina. Se identificaron interacciones medicamentosas potencialmente dañinas en el $25 \%$ (75) siendo las más frecuentes las de IECA + $\operatorname{AINE}(53,3 \%)$, IECA + amilorida / hidroclorotiazina (22,6\%).

Conclusiones: El uso de antihipertensivos ha cambiado significativamente hacia los IECA y los BCC dihidropiridínicos de larga acción. El uso de tiazidas y metildopa ha disminuido significativamente. Parece que los médicos están más concienciados de los beneficios a largo plazo cardio y renovasculares asociados al uso de IECA en un grupo de alto riesgo cardiovascular como los hipertensos negros.

Palabras clave: Antihipertensivos; Inhibidores de la Enzima Convertidora de Angiotensina; Bloqueadores de los Canales de Calcio; Utilización de Medicamentos; Nigeria

\section{References}

1. World Health Report: Reducing risks, promoting healthy life. Geneva, Switzerland: World Health Organization.2002. http://www.who.int/whr/2002/ (Accessed Feb 14, 2014).

2. Lewington S, Clarke R, Qizilbash N, Peto R, Collins R; Prospective Studies Collaboration. Age-specific relevance of usual blood pressure to vascular mortality: A meta-analysis of individual data for one million adults in 61 prospective studies. Lancet. 2002;360(9349):1903-1913.

3. Vasan RS, Larson MG, Leip EP, Evans JC, O'Donnell CJ, Kannel WB, Levy D. Impact of high normal blood pressure on the risk of cardiovascular disease. N Engl J Med. 2001;345(18):1291-1297.

4. James PA, Oparil S, Carter BL, Cushman WC, Dennison-Himmelfarb C, Handler J, Lackland DT, LeFevre ML, MacKenzie TD, Ogedegbe O, Smith SC Jr, Svetkey LP, Taler SJ, Townsend RR, Wright JT Jr, Narva AS, Ortiz E. 2014 Evidence-Based Guideline for the Management of High Blood Pressure in Adults. Report From the Panel Members 
Appointed to the Eighth Joint National Committee (JNC 8). JAMA. 2014;311(5):507-520. doi: 10.1001/jama.2013.284427

5. Mancia G, Fagard R, Narkiewicz K, Redon J, Zanchetti A, Böhm M, Christiaens T, Cifkova R, De Backer G, Dominiczak A, Galderisi M, Grobbee DE, Jaarsma T, Kirchhof P, Kjeldsen SE, Laurent S, Manolis AJ, Nilsson PM, Ruilope LM, Schmieder RE, Sirnes PA, Sleight P, Viigimaa M, Waeber B, Zannad F, Redon J, Dominiczak A, Narkiewicz K, Nilsson PM, Burnier M, Viigimaa M, Ambrosioni E, Caufield M, Coca A, Olsen MH, Schmieder RE, Tsioufis C, van de Borne P, Zamorano JL, Achenbach S, Baumgartner H, Bax JJ, Bueno H, Dean V, Deaton C, Erol C, Fagard R, Ferrari R, Hasdai D, Hoes AW, Kirchhof P, Knuuti J, Kolh P, Lancellotti P, Linhart A, Nihoyannopoulos P, Piepoli MF, Ponikowski P, Sirnes PA, Tamargo JL, Tendera M, Torbicki A, Wijns W, Windecker S, Clement DL, Coca A, Gillebert TC, Tendera M, Rosei EA, Ambrosioni E, Anker SD, Bauersachs J, Hitij JB, Caulfield M, De Buyzere M, De Geest S, Derumeaux GA, Erdine S, Farsang C, Funck-Brentano C, Gerc V, Germano G, Gielen S, Haller H, Hoes AW, Jordan J, Kahan T, Komajda M, Lovic D, Mahrholdt H, Olsen MH, Ostergren J, Parati G, Perk J, Polonia J, Popescu BA, Reiner Z, Rydén L, Sirenko Y, Stanton A, Struijker-Boudier H, Tsioufis C, van de Borne P, Vlachopoulos C, Volpe M, Wood DA. 2013 ESH/ESC guidelines for the management of arterial hypertension: the Task Force for the Management of Arterial Hypertension of the European Society of Hypertension (ESH) and of the European Society of Cardiology (ESC). Eur Heart J. 2013;34(28):2159-219. doi: 10.1093/eurheartj/eht151

6. Flack JM, Sica DA, Bakris G, Brown AL, Ferdinand KC, Grimm RH Jr, Hall WD, Jones WE, Kountz DS, Lea JP, Nasser S, Nesbitt SD, Saunders E, Scisney-Matlock M, Jamerson KA; International Society on Hypertension in Blacks. Management of high blood pressure in Blacks: an update of the International Society on Hypertension in Blacks consensus statement. Hypertension. 2010;56(5):780-800. doi: 10.1161/HYPERTENSIONAHA.110.152892

7. Kadiri S, Olutade BO. The clinical presentation of malignant hypertension in Nigerians. J Hum Hypertens. 1991;5(4):339-343.

8. Kadiri S, Olutade BO, Osobamiro O. Factors influencing the development of malignant hypertension in Nigeria. J Hum Hypertens. 2000;14(3):171-174

9. Yusuff KB, Balogun OB. Pattern of drug utilization among hypertensives in a Nigerian teaching hospital. Pharmacoepidemiol Drug Saf. 2005;14(1):69-74.

10. Etuk E, Isuezo SA, Chika A, Akuche J, Ali M. Prescription pattern of antihypertensive drugs in a tertiary health institution in Nigeria. Ann Afr Med. 2008;7(3):128-132.

11. Adigun AQ, Ishola DA, Akintomide AO, Ajayi AA. Shifting trends in the pharmacologic treatment of hypertension in a Nigerian tertiary hospital: a real-world evaluation of the efficacy, safety, rationality and pharmaco-economics of old and newer antihypertensive drugs. J Hum Hypertens. 2003;17(4):277-285.

12. Tamuno I. Fadare J. Drug treatment for hypertension in a tertiary health care facility in Northern Nigeria. Int J Pharm Biomed Res. 2011;2(2):104-109.

13. Katibi IA. Olarinoye JK. Antihypertensive therapy among hypertensive patients as seen in the middle belt of Nigeria. Ann Afr Med 2004;3:177-180.

14. Yusuff KB, Balogun O. Physicians' prescribing of antihypertensive combinations in a tertiary care setting in Southwestern Nigeria. J Pharm Pharm Sci. 2005;8(2):235-242.

15. ALLHAT Officers and Coordinators for the ALLHAT Collaborative Research Group. The Antihypertensive and LipidLowering Treatment to Prevent Heart Attack Trial. Major outcomes in high-risk hypertensive patients randomized to angiotensin-converting enzyme inhibitor or calcium channel blocker vs diuretic: The Antihypertensive and LipidLowering Treatment to Prevent Heart Attack Trial (ALLHAT). JAMA. 2002;288(23):2981-2997.

16. Lopes AA. Hypertension in black people: pathophysiology and therapeutic aspects. J Hum Hypertens. 2002;16(Suppl 1):S11-S2.

17. Mokwe E, Ohmit SE, Nasser SA, Shafi T, Saunders E, Crook E, Dudley A, Flack JM. Determinants of blood pressure to quinapril in black and white hypertensive patients: the Quinapril Titration Interval Management Evaluation Trial. Hypertension. 2004;43(6):1202-1207.

18. Flack JM1, Yunis C, Preisser J, Holmes CB, Mensah G, McLean B, Saunders E: ATIME Research Group. The rapidity of drug dose escalation influences blood pressure response and adverse effects burden in patients with hypertension: the Quinapril Titration Interval Management Evaluation (ATIME) Study. Arch Intern Med. 2000;160(12):1842-1827.

19. Fenves $A$, Ram CV. Are angiotensin converting enzyme inhibitors and angiotensin receptor blockers becoming the treatment of choice in African-American? Curr Hypertens Rep. 2002 Aug;4(4):286-289.

20. Douglas JG, Agodoa L. ACE inhibiton is effective and renoprotective in hypertensive nephrosclerosis: the African American Study of Kidney Disease and Hypertension (AASK) trial. Kidney Int Suppl. 2003;(83):S74-S76.

21. Kizer JR, Arnett DK, Bella JN, Paranicas M, Rao DC, Province MA, Oberman A, Kitzman DW, Hopkins PN, Liu JE, Devereux RB. Differences in left ventricular structure between black and white hypertensive adults: the Hypertension Genetic Epidemiology Network study. Hypertension. 2004;43(6):1182-1188.

22. Bild DE, Bluemke DA, Burke GL, Detrano R, Diez Roux AV, Folsom AR, Greenland P, Jacob DR Jr, Kronmal R, Liu K, Nelson JC, O'Leary D, Saad MF, Shea S, Szklo M, Tracy RP. Multi-ethnic study of atherosclerosis: objectives and design. Am J Epidemiol. 2002;156(9):871-881.

23. Chobanian AV, Bakris GL, Black HR, Cushman WC, Green LA, Izzo JL Jr, Jones DW, Materson BJ, Oparil S, Wright JT Jr, Roccella EJ; Joint National Committee on Prevention, Detection, Evaluation, and Treatment of High Blood Pressure. National Heart, Lung, and Blood Institute; National High Blood Pressure Education Program Coordinating Committee. Seventh report of the Joint National Committee on Prevention, Detection, Evaluation, and Treatment of High Blood Pressure. Hypertension. 2003;42(6):1206-1252.

24. British National Formulary (BNF). London: BMJ Publishing Group and Royal Pharmaceutical Society of Great Britain; 2010.

25. Elliott WJ, Meyer PM. Incident diabetes in clinical trials of antihypertensive drugs: a network meta-analysis. Lancet. 2007;369(9557):201-207. 
26. Carlsen JE, Køber L, Torp-Pedersen C, Johansen P. Relation between dose of bendrofluazide, antihypertensive effect, and adverse biochemical effects. BMJ. 1990;300(6730):975-978.

27. Barzilay JI, Davis BR, Cutler JA, Pressel SL, Whelton PK, Basile J, Margolis KL, Ong ST, Sadler LS, Summerson J; ALLHAT Collaborative Research Group. Fasting glucose levels and incident diabetes mellitus in older nondiabetic adults randomized to receive 3 different classes of antihypertensive treatment: a report from the Antihypertensive and Lipid-Lowering Treatment to Prevent Heart Attack Trial (ALLHAT). Arch Intern Med. 2006;166(20):2191-2201.

28. Zillich AJ, Garg J, Basu S, Bakris GL, Carter BL. Thiazide diuretics, potassium, and the development of diabetes: a quantitative review. Hypertension. 2006;48(2):219-224.

29. Carter BL, Einhorn PT, Brands M, He J, Cutler JA, Whelton PK, Bakris GL, Brancati FL, Cushman WC, Oparil S, Wright JT Jr; Working Group from the National Heart, Lung, and Blood Institute. Thiazide-induced dysglycemia: call for research from a working group from the national heart, lung, and blood institute. Hypertension. 2008;52(1):30-6. doi: 10.1161/HYPERTENSIONAHA.108.114389

30. Franse LV, Pahor M, Di Bari M, Somes GW, Cushman WC, Applegate WB. Hypokalemia associated with diuretic use and cardiovascular events in the Systolic Hypertension in the Elderly Program. Hypertension. 2000;35(5):1025-1030.

31. Parati G, Pomidossi G, Albini E, Malaspina D, Mancia G. Relationship of 24 hour blood pressure mean and variability to severity of target organ damage in hypertension. J Hypertens. 1987;5(1):93-98.

32. Thomas MC. Diuretics, ACE inhibitors and NSAIDS - the triple whammy. Med J Aust. 2000;172(4):184-185.

33. Abuelo JG. Normotensive ischemic acute renal failure. N Engl J Med. 2007;357(8):797-805.

34. Morgan T, Anderson A. The effect of non-steroidal anti-inflammatory drugs on blood pressure in patients treated with different anti-hypertensive drugs. J Clin Hypertens (Greenwich). 2003;5(1):53-57.

35. White WB. Cardiovascular effects of the cyclooxygenase inhibitors. Hypertension. 2007;49(3):408-418.

36. Radosević N, Gantumur M, Vlahović-Palcevski V. Potentially inappropriate prescribing to hospitalized patients. Pharmacoepidemiol Drug Saf. 2008;17(7):733-737. 